\title{
CORRESPONDENCE.
}

\section{RARE CAPTURES.}

Dear Sir: In my letter with this heading in the March number, p. 60 , there is an omission of a word which quite alters my meaning. Line 6 of my letter should read, "I concluded that I had not seen it before." I took Pedisca nisella, referred to at the same time, last August, about twenty miles north of Hamilton, in the County of Halton. I found it sitting on the trunks of small birch and poplar trees.

J. Alston Moffat, Hamilton, Ont.

\section{GRAPTA INTERROGATIONIS AT MONTREAL.}

Dear Sir: I was somewhat surprised to see the capture of the above species at Montreal recorded as being an unusual and almost unknown occurrence (Feb. number, page 40). In Mr. Caulfield's list, Cax. EnT., VII., 87, Interrogationis is given, "Rare; May (hibernated); July to October," and I have always considered it one of those species which are neither rare nor abundant. The first specimen $I$ have any record of was taken by me in Mr. Trenholme's garden, Rosemount Ave., Cote St. Antoine, on Sept. 7 th, 1886 . In the fall of 1887 it was abundant at Mr. Trenholme's, and a number of specimens (all Fabricii) were taken; between that time and the present I know of about 40 other specimens being captured in various parts of the town, and I succeeded in rearing three separate lots of larvæ to imago during last fall, all feeding on elm leaves. The form "umbrosa" seems to be much rarer here than Fabricii, but a few have been taken by Mr. P. M. Dawson and other collectors. I saw a single specimen of Interrogationis at St. Rose, P. Q., July 6 th, 1889 , but was unable to catch it.

Albert F. Winn, Montreal, P. Q.

ERrata.-The following corrections should be made in Dr. Hamilton's paper on "Balaninus" in the January number:-Page $\mathrm{s}$, line 23 , and elsewhere, for "proboscoideus" read "proboscideus." Page 5, line 33, for "nostrum" read "rostrum." Page 6 , line 34 , for "three first" read "first three." 